\title{
SEGALEN, Martine. 2002. Ritos e rituais contemporâneos.
}

Rio de Janeiro: Editora FGV. 161pp.

Valéria Oliveira Santos PPGAS/UFPR
Publicado originalmente em francês no ano de 1998, o livro Ritos e Rituais Contemporâneos constitui a primeira obra de Martine Segalen - ligada ao Institut Parisien de Recherche en Architecture Urbanistique et Société e ex-diretora do Centre d'Ethnologie Française - disponível em língua portuguesa. Dedicada à identificação de práticas rituais na contemporaneidade e endereçada a leigos e estudantes, a obra faz parte de um conjunto de reflexões mais recentes da autora, que é mais conhecida por suas publicações na área de família e parentesco. Seu interesse pelos rituais em sociedades contemporâneas, uma temática relativamente distante dos estudos de família, se fez notar primeiramente em 1994 com a publicação de Les enfants d'Achille et de Nike. Une ethnologie de la course à pied ordinaire, que trata de grandes maratonas.

O objetivo de Ritos e Rituais Contemporâneos é reunir, em breves 150 páginas, as principais contribuições de autores clássicos e contemporâneos para a teoria dos rituais. Além disso, Segalen pretende demonstrar que "apesar do" ou "concomitantemente ao" privilégio do "indivíduo sobre o coletivo" (:34) na atualidade, é possível identificar uma reconfiguração das práticas rituais e constatar a permanência das mesmas.

A autora investe na idéia de que "uma das principais características do rito é a sua plasticidade, a sua capacidade de ser polissêmico, de acomodar-se à mudança social" (:15), o que lhe permite argumentar contra perspectivas que relacionam as sociedades modernas ao império do pensamento racional e à ausência de ritos. Desta forma, o livro é capaz de despertar o interesse pela leitura dos autores indicados e o aprofundamento da discussão, pois organizase de modo a demonstrar o potencial explicativo de clássicos da sociologia e da Campos 4:217-220, 2003. antropologia na abordagem de temas atuais. 
O primeiro capítulo, "Rito, sagrado, símbolo" sintetiza as proposições teóricas clássicas de Émile Durkheim e Marcel Mauss e seus desdobramentos nas reflexões de autores contemporâneos como Mary Douglas. A autora destaca passagens que captam a plasticidade dos ritos, sua capacidade de assumir formatos adequados às novas circunstâncias sociais, pois considera que estes deixaram de ocupar um lugar central na vida contemporânea. “Mais do que falar em desritualização, podemos agora pensar num deslocamento do campo do ritual. Do centro do social os ritos se deslocaram, na maioria das vezes, para sua margem. Eles são encontrados no domínio dos esportes, do extralaboral (ou na dimensão extralaboral do trabalho, como festas de aposentadoria, aniversários, nascimentos de filhos de funcionários etc.)" (:36).

Ao mesmo tempo, Segalen se preocupa com o que considera uma difusão abusiva dos termos rito e ritual, "que arrisca fazê-los perder toda sua eficácia semântica" (:13). Assim, a autora define: "o rito ou ritual é um conjunto de atos formalizados, expressivos, portadores de uma dimensão simbólica. O rito é caracterizado por uma configuração espaço-temporal específica, pelo recurso a uma série de objetos, por sistemas de linguagens e comportamentos específicos e por signos emblemáticos cujo sentido codificado constitui um dos bens comuns do grupo" (:31).

No segundo capítulo, "A questão dos ritos de passagem", Martine Segalen apresenta as contribuições de Arnold Van Gennep e de Victor Turner sobre o processo ritual. No primeiro autor, Segalen preza o estudo do ritual em sua totalidade, a comparação contextualizada e a valorização dos atores sociais. Em Turner, o que recebe atenção é a noção de liminaridade como um estágio ritual que torna possível, momentaneamente, um posicionamento fora das hierarquias, das classes e da ordem social. Seguem-se, então, descrições de ritos relativos ao nascimento, ao casamento e à morte. A autora considera que, na atualidade, esses rituais foram afastados de seu caráter público e se tornaram, cada vez mais, rituais privados, o que significaria um "déficit ritual" (:57), uma privação do apoio coletivo. Casamentos, por exemplo, teriam deixado de marcar passagens, segundo a autora, para conferir publicidade a um “ato de compromisso que já foi estabelecido há muito tempo através de pequenas etapas" (:57).

O trote, um "percurso de provas que procura testar a resistência física e psicológica do noviço" (:64) é, em contraste, apontado como um rito de passagem que mantém seu caráter público. Ao escolher este exemplo, Martine Segalen reafirma o ponto de vista de que a permanência dos ritos na contemporaneidade está relegada ao domínio do "extralaboral" e dos "esportes", isto é, a dimensões mais ou menos intersticiais da vida social. Pois ainda que nem sempre sejam "subterrâneos e marginais" (:36), no sentido de que tais rituais podem se fazer publicamente visíveis (como comemorações pela vitória em um campeonato de futebol), os rituais contemporâneos estariam presentes apenas nos espaços não ocupados pela racionalidade do mercado e do Estado. Desse modo, 
a autora admite implicitamente um problemático divisor entre o "racional" e o "simbólico", reservando a este último um papel secundário na dinâmica social contemporânea.

No capítulo três, intitulado "Homens, esportes, ritos", Segalen disserta sobre as caçadas, as touradas, o futebol e sobre as corridas e maratonas. Atividades coletivas que, segundo a antropóloga, "oferecem saídas para as imposições regulamentadas do quotidiano, abrindo espaço à integração e propondo aos nossos imaginários a escapatória de suas simbolizações" (:69). Persiste aqui, portanto, a falsa dicotomia apontada há pouco. De um lado, a racionalidade desprovida de símbolos. De outro, o espaço do apoio coletivo, da simbolização como uma escapatória, marginal e extra-cotidiana. Os ritos permanecem, mas perifericamente e em atividades que parecem constituir um "reservatório de ritual para nossas sociedades modernas" (:69) e "se sobrepõem às atividades racionais" (: 88). Para Segalen, as corridas e maratonas reúnem nas ruas uma multidão que "parece ter uma energia que se comunica ao longo da cadeia humana" (:85). Mas é a caça, segundo a autora, que "provavelmente leva mais longe a associação com o selvagem" (:88) pois, "quanto mais antiga a atividade, mais ela toca os fluidos corporais maiores e mais forte será sua carga simbólica" (:89).

Não por acaso, ao final do capítulo a distinção entre o que é e o que não é ritual se mostra imprecisa. Embora o esporte e o lazer sejam concebidos como os espaços por excelência da ritualização nas sociedades contemporâneas, a autora considera que "nem todas as atividades lúdicas se prestam às operações de simbolização que fazem parte da função ritualizante" (:89). Esportes como esqui e tênis seriam muito técnicos e fragilmente simbólicos: "tais atividades são praticadas por praticar e nada dizem fora delas mesmas" (:89). Ficam as dúvidas: por que uma técnica apurada implicaria um simbolismo frágil? Aliás, o que seria um símbolo frágil?

No quarto capítulo, "O secular e o singular: a função comunicativa do rito", a autora trata dos ritos políticos, dos ritos urbanos festivos e dos ritos nas empresas, afastando-se até certo ponto de algumas proposições anteriores. Aqui, Martine Segalen enfatiza o fato de que o rito é uma experiência compartilhada de significação e considera que "a tradição se articula a comportamentos cuja repetitividade fornece um quadro à inteligibilidade compartilhada dos fatos" (: 91). Portanto, a "adesão ao símbolo" seria a responsável por fazer com que uma seqüência cerimonial constitua um ritual. Nessa perspectiva, as festas nacionais promovidas pelo governo e articuladas por uma elite política podem ou não constituir rituais genuínos, de acordo com a adesão simbólica que conseguem arregimentar na população.

Em passagem sobre a participação da mídia nos rituais contemporâneos, Segalen cita o casamento e a morte de lady Diana como rituais de passagem que foram reforçados pela transmissão televisiva internacional. No caso do enterro, a autora considera que "de certa forma o povo impôs sua vontade aos soberanos britânicos", uma vontade e emoção "subversivas" (:105). "Os telespectadores não constituem uma massa passiva mas 
Valéria Oliveira Santos

compartilham a recepção de imagens abundantemente comentadas e que os colocam, também nesse caso, em situação de communitas" (:106).

É no último capítulo, intitulado "Plasticidade, polissemia, mudança social: o exemplo do casamento", que os dados etnográficos e históricos recebem um tratamento mais cuidadoso, fruto da intimidade da autora com o tema e de uma observação mais acurada dos sentidos dados pelos próprios atores sociais ao rito. Ao descrever a dinâmica dos rituais no interior e na capital francesa em três períodos distintos, 1930-60, 1960-70 e, por último, na atualidade, a autora demonstra que os atores sociais promovem mudanças tanto no formato quanto nos significados dos ritos, e acabam por cristalizar novas seqüências rituais. O casamento possui agora novos significados, novos formatos e um novo espaço, distanciado do sagrado, o que, para Segalen, seria a demonstração por excelência do caráter plástico dos rituais, que Ihes confere a possibilidade de permanecerem rituais mesmo sendo adequados continuamente a novos contextos sociais.

Em termos gerais, é possível dizer que Martine Segalen produziu uma introdução sucinta e que não pretende oferecer uma síntese definitiva de uma temática tão ampla e fecunda como a dos rituais. Ao contrário, a obra dá indicações clássicas de leitura e reafirma o rendimento teórico do tema. Vale ressaltar, entretanto, que, diferentemente de outros pesquisadores contemporâneos - como é o caso de Stanley J. Tambiah, referência ausente no trabalho da autora - Segalen insiste em oferecer uma definição específica do que é ritual. Também exige atenção o fato de que, ao argumentar contra aqueles que pensam as sociedades contemporâneas como mundos da ausência ritual, a autora acaba por reforçar um discutível dualismo entre o "racional" e o "simbólico" que limita os rituais a espaços periféricos nas sociedades contemporâneas.

Valéria Oliveira Santos é mestranda no Programa de Pós-Graduação em Antropologia Social da UFPR. 